\title{
PENGELOMPOKAN WILAYAH MENURUT POTENSI FASILITAS KESEHATAN DAN KEJADIAN COVID-19 MENGGUNAKAN ALGORITMA FUZZY K- PROTOTYPES
}

\author{
Hermawan Prasetyo \\ Badan Pusat Statistik Provinsi Jawa Tengah \\ email: herpas@bps.go.id
}

\begin{abstract}
Abstrak
COVID-19 telah masuk ke Indonesia dan menyebar ke seluruh wilayah Indonesia hingga saat ini. Penanganan COVID-19 tidak lepas dari peran fasilitas kesehatan dalam pengendalian COVID-19. Fasilitas kesehatan merupakan potensi suatu wilayah, yang dapat diperoleh datanya melalui PODES. Data terkait fasilitas kesehatan pada suatu wilayah dapat dianalisis dengan metode clustering. Metode ini dapat dilakukan pada tipe data numerik, kategorik, dan campuran. Pada penelitian ini dilakukan pengelompokan wilayah desa di Kota Semarang menjadi dua klaster dengan algoritma fuzzy k-prototypes. Dari hasil pengelompokan dapat dilihat bahwa klaster 2 memiliki rata-rata jumlah fasilitas kesehatan, persentase kejadian COVID-19, dan rata-rata jumlah penderita COVID-19 yang lebih tinggi dibandingkan klaster 1. Jumlah fasilitas kesehatan juga berbanding lurus dengan jumlah kejadian dan penderita COVID-19. Akan tetapi, jumlah fasilitas kesehatan yang ada mengalami ketimpangan jika dibandingkan jumlah kejadian dan penderita COVID-19. Hal ini dapat dijadikan masukan bagi Pemerintah Kota Semarang dalam menangani COVID-19 pada wilayah yang mengalami ketimpangan jumlah fasilitas kesehatan.
\end{abstract}

Keywords: COVID-19, fasilitas kesehatan, clustering, potensi desa

\section{PENDAHULUAN}

Pada awal tahun 2020 coronavirus jenis baru (SARS-CoV-2) dengan penyakitnya yang disebut Coronavirus disease 2019 (COVID19)[1]. Virus ini berawal dari laporan dari Tiongkok kepada World Health Organization (WHO), yaitu terdapat 44 pasien pneumonia berat di Wuhan pada akhir tahun 2019[2]. COVID-19 telah masuk ke Indonesia pertama kali dilaporkan tanggal 2 Maret 2020[3]. Virus ini kemudian menyebar sampai ke seluruh wilayah Indonesia hingga mencapai 2.615 .529 orang yang terkonfirmasi COVID-19 pada 14 Juli 2021[4].

Di tengah pandemi COVID-19, peran fasilitas kesehatan tingkat pertama sangat penting dalam melakukan prevalensi, deteksi, dan respon dalam pencegahan dan pengendalian COVID19[5]. Pelayanan primer di bidang kesehatan seperti puskesmas, klinik pratama, dan dokter praktik mandiri sebagai ujung tombak pelayanan kesehatan harus bergerak membantu memotong mata rantai penularan[6]. Selain itu, apotek juga berperan penting dalam masa pandemi. Apoteker dalam apotek memberikan layanan kefarmasian untuk mengurangi beban pasien di fasilitas kesehatan seperti rumah sakit dan praktik dokter umum[6].

Fasilitas kesehatan merupakan salah satu potensi wilayah, yang tersebar di seluruh wilayah Indonesia. Badan Pusat Statistik (BPS) mengumpulkan data potensi wilayah melalui Pendataan Potensi Desa (PODES)[7]. Data yang dikumpulkan dalam PODES termasuk data tentang kesehatan, antara lain fasilitas kesehatan dan kejadian wabah, termasuk COVID-19. Tipe data yang ada pada data PODES berupa data numerik dan kategorik.

Analisis potensi wilayah dapat dilakukan dengan clustering. Clustering atau pengelompokan merupakan teknik dalam data mining yang menghasilkan kelompok-kelompok objek dengan objek-objek di dalam klaster sangat mirip dan objek-objek di luar klaster tidak 
mirip[8]. Clustering dapat dilakukan pada tipe data numerik, kategorik, dan campuran keduanya. Salah satu metode clustering untuk data beratribut campuran adalah algoritma $k$ prototypes[9]. Dalam perkembangannya, algoritma ini dikembangkan menjadi algoritma fuzzy k-prototypes (FKP)[10].

Penelitian ini bertujuan untuk pengelompokan potensi kesehatan wilayah dengan metode FKP clustering. Variabel yang digunakan untuk pengelompokan yaitu jumlah fasilitas kesehatan, adanya kejadian COVID-19, dan jumlah penderita COVID-19. Data diambil dari PODES tahun 2020 yang menyajikan data potensi wilayah hingga tingkat desa. Adapun wilayah dalam penelitian ini adalah wilayah desa di Kota Semarang. Hasil penelitian ini diharapkan dapat menjadi bahan masukan bagi Pemerintah Kota Semarang dalam melihat potensi kesehatan dan kejadian COVID-19 suatu wilayah sehingga mempermudah dalam penanganan COVID-19.

\section{METODE PENELITIAN}

Pada penelitian ini dilakukan pengelompokan data potensi fasilitas kesehatan wilayah dan kejadian COVID-19 dengan menggunakan algoritma FKP. Untuk mendapatkan hasil pengelompokan dilakukan beberapa tahap, yaitu penyiapan data, data preprocessing, pemrosesan data, dan evaluasi.

\section{a. Penyiapan Data}

Data potensi fasilitas kesehatan dapat diambil dari hasil Pendataan Potensi Desa (PODES)[7]. Dataset yang digunakan dalam penelitian ini adalah data potensi fasilitas kesehatan dan kejadian COVID-19 yang diperoleh dari hasil PODES tahun 2020 (PODES2020-DESA). Adapun wilayah yang dipilih adalah Kota Semarang. Dataset terdiri dari 177 record, tiap record mewakili satu desa.

\section{b. Data Preprocessing}

Tahap selanjutnya yang dilakukan adalah tahap data preprocessing. Pada tahap ini dilakukan pemilihan atribut yang digunakan untuk pengelompokan data. Atribut dipilih dari dataset PODES2020-DESA pada Blok VI Pendikan dan Kesehatan. Atribut terpilih terdiri dari atribut dengan tipe data numerik dan kategorik.

Tabel 1. Atribut Terpilih pada Dataset PODES2020-DESA

\begin{tabular}{|c|c|c|c|}
\hline No & Rincian & Deskripsi & Tipe Data \\
\hline 1 & R603a & $\begin{array}{l}\text { Jumlah rumah } \\
\text { sakit }\end{array}$ & Numerik \\
\hline 2 & $\mathrm{R} 603 \mathrm{c}$ & $\begin{array}{l}\text { Jumlah } \\
\text { puskesmas } \\
\text { dengan rawat } \\
\text { inap }\end{array}$ & Numerik \\
\hline 3 & R603d & $\begin{array}{l}\text { Jumlah } \\
\text { puskesmas tanpa } \\
\text { rawat inap }\end{array}$ & Numerik \\
\hline 4 & R603e & $\begin{array}{l}\text { Jumlah } \\
\text { puskesmas } \\
\text { pembantu }\end{array}$ & Numerik \\
\hline 5 & R603f & $\begin{array}{l}\text { Jumlah } \\
\text { poliklinik/balai } \\
\text { pengobatan }\end{array}$ & Numerik \\
\hline 6 & R603g & $\begin{array}{l}\text { Jumlah tempat } \\
\text { praktik dokter }\end{array}$ & Numerik \\
\hline 7 & R6031 & Jumlah apotek & Numerik \\
\hline 8 & R605hK2 & $\begin{array}{l}\text { Kejadian } \\
\text { COVID-19 }\end{array}$ & Kategorik \\
\hline 9 & R605hK3 & $\begin{array}{l}\text { Jumlah } \\
\text { penderita } \\
\text { COVID-19 }\end{array}$ & Numerik \\
\hline
\end{tabular}

Pada tahap ini juga dilakukan data preprocessing berupa agragasi nilai atribut. Tujuan agregasi adalah agar mendapatkan satu atribut baru dari beberapa atribut yang ada. Agregasi dilakukan pada atribut R603a, R603c, R603d，R603e，R603f， R603g， dan R6031 menjadi atribut baru R603, yaitu jumlah fasilitas kesehatan. Adapun hasil agregasi dapat dilihat pada Tabel 2.

Tabel 2. Hasil Agregasi Atribut

\begin{tabular}{clll}
\hline No & Rincian & \multicolumn{1}{c}{ Deskripsi } & Tipe Data \\
\hline 1 & R603 & $\begin{array}{l}\text { Jumlah fasilitas } \\
\text { kesehatan }\end{array}$ & Numerik \\
2 & R605hK2 & $\begin{array}{l}\text { Kejadian } \\
\text { COVID-19 }\end{array}$ & Kategorik \\
& & $\begin{array}{l}\text { Jumlah } \\
\text { penderita } \\
\text { COVID-19 }\end{array}$ & Numerik \\
& R605hK3 & \\
& & & \\
\hline
\end{tabular}

\section{c. Pemrosesan Data}


Dari dataset yang telah siap kemudian dilakukan pemrosesan clustering data menggunakan algoritma FKP[10]. Algoritma FKP merupakan pengembangan dari algoritma $k$ prototypes yang diusulkan oleh Huang [9]. Misalkan $X$ adalah suatu himpunan objek $X_{1}, X_{2}, \ldots, X_{n}$ dengan atribut numerik $A_{1}, A_{2}, \ldots, A_{p}$ dan atribut kategorik $A_{1}, A_{2}, \ldots, A_{q}$ serta $k$ adalah jumlah klaster. Algoritma FKP dilakukan dengan meminimalkan objective function $F(W, Z)$, yang didefinisikan pada Persamaan 1.

$$
F(W, Z)=\sum_{l=1}^{k} \sum_{i=1}^{n} w_{l i}^{\alpha} d\left(X_{i}, Z_{l}\right)
$$

dengan $\propto \geq 1$ adalah suatu parameter fuzzy, $W=\left\{w_{l i}\right\}$ adalah suatu matriks keanggotaan berukuran $k \times n$, dan $Z=\left\{Z_{1}, Z_{2}, \ldots, Z_{k}\right\}$ adalah suatu himpunan $k$ prototipe dengan $m$ dimensi.

Algoritma FKP didefinisikan sebagai[10]:

(1) Pilih satu himpunan prototipe awal $Z^{(l)}$ dan satu pengontrol iterasi $\varepsilon$.

(2) Tentukan $W^{(l)}$ yang meminimalkan $F\left(W, Z^{(l)}\right)$. Set $i=1$.

(3) Tentukan $Z^{(i+1)}$ yang meminimalkan $F\left(W^{(i)}, Z\right) . \quad$ Jika $\quad \mid F\left(W^{(i)}, Z^{(i+1)}\right)-$ $F\left(W^{(i)}, Z^{(i)}\right) \mid<\varepsilon$, maka berhenti. Jika tidak, maka set $\left(W^{*}, Z^{*}\right)=\left(W^{(i)}, Z^{(i+1)}\right)$.

(4) Tentukan $W^{(i+1)}$ yang meminimalkan $F\left(W, Z^{(i+1)}\right)$. Jika $\mid F\left(W^{(i+1)}, Z^{(i+1)}\right)-$ $F\left(W^{(i)}, Z^{(i+1)}\right) \mid<\varepsilon$, maka berhenti. Jika tidak, maka set $\left(W^{*}, Z^{*}\right)=\left(W^{(i+1)}, Z^{(i+1)}\right)$. Tambahkan $i$ dengan 1 dan kembali ke langkah (3).

\section{d. Evaluasi}

Setelah dilakukan pemerosesan data dengan algoritma FKP, langkah selanjutnya adalah evaluasi hasil pengelompokan. Metode evaluasi dalam penelitian ini adalah dengan indeks partition coefficient (PC) dan indeks partition entropy (PE)[8].

Indeks PC dapat dihitung dengan Persamaan 2 sebagai berikut,

$$
V_{P C}=\frac{1}{n} \sum_{l=1}^{c} \sum_{i=1}^{n} w_{l i}^{2}
$$

dengan $W=\left(w_{l i}\right)(1 \leq l \leq c, 1 \leq i \leq n)$ adalah matriks keanggotaan dari $c$ partisi fuzzy dari dataset $D$ dengan $n$ objek. Nilai indeks PC yang semakin mendekati 1 menandakan bahwa hasil pengelompokan semakin tepat.

Indeks PE dapat dihitung dengan Persamaan 3 sebagai berikut,

$$
V_{P E}=-\frac{1}{n} \sum_{l=1}^{c} \sum_{i=1}^{n} w_{l i} \log _{a}\left(w_{l i}\right)
$$

dengan $a$ adalah bilangan basis logaritma dan $W=\left(w_{l i}\right)$ adalah matriks keanggotaan dari $c$ partisi fuzzy. Nilai indeks PE yang semakin mendekati 0 menandakan bahwa hasil pengelompokan semakin tepat.

\section{HASIL DAN PEMBAHASAN}

Clustering dilakukan pada data PODES 2020 pada beberapa jumlah klaster. Nilai koefisien fuzziness $(\alpha)$ yang dipilih sebesar 2 , yaitu nilai yang paling banyak digunakan pada fuzzy clustering[11]. Data diolah menggunakan software MATLAB. Hasil indeks PC dan PE berdasarkan beberapa percobaan dapat dilihat pada Tabel 3.

Tabel 3. Nilai indeks PC dan PE

\begin{tabular}{ccc}
\hline Jumlah klaster & $\begin{array}{c}\text { Indeks } \\
\text { PC }\end{array}$ & $\begin{array}{c}\text { Indeks } \\
\text { PE }\end{array}$ \\
\hline 2 & 0,6805 & 0,4886 \\
3 & 0,5081 & 0,8409 \\
4 & 0,4201 & 1,0821 \\
5 & 0,3580 & 1,2788 \\
\hline
\end{tabular}

Dari hasil indeks PC dan PE pada Tabel 3 dapat dilihat bahwa hasil clustering terbaik terjadi pada saat jumlah klaster sebanyak dua. Pada jumlah kluster dua, nilai indeks PC paling tinggi dibandingkan jumlah klaster yang lain. Demikian juga dengan nilai indeks PE pada jumlah klaster dua paling rendah di antara jumlah klaster lainya.

Clustering data menjadi dua klaster

\begin{tabular}{|c|c|c|}
\hline Variabel & $\begin{array}{c}\text { Klaster } \\
1\end{array}$ & $\begin{array}{c}\text { Klaster } \\
2\end{array}$ \\
\hline $\begin{array}{l}\text { Jumlah fasilitas } \\
\text { kesehatan }\end{array}$ & 4,6533 & 9,0202 \\
\hline $\begin{array}{l}\text { Kejadian COVID- } \\
19\end{array}$ & Ada & Ada \\
\hline $\begin{array}{l}\text { Jumlah penderita } \\
\text { COVID-19 }\end{array}$ & 2,9871 & 4,4027 \\
\hline
\end{tabular}
menghasikan nilai centroid seperti pada Tabel 4.

Tabel 4. Nilai centroid hasil clustering 
Dari Tabel 4 dapat dilihat bahwa berdasarkan nilai centroid, terdapat perbedaan antara klaster 1 dan 2 pada variabel jumlah fasilitas kesehatan dan jumlah penderita COVID19. Pada klaster 1, nilai centroid jumlah fasilitas kesehatan sebesar 4,6533 sedangkan pada klaster 2 sebesar 9,0202. Untuk variabel jumlah penderita COVID-19, nilai centroid klaster 1 sebesar 2,9871 dan klaster 2 sebesar 4,4027. Jika dilihat dari variabel kejadian COVID-19, kedua klaster memiliki nilai centroid yang sama yaitu ada kejadian COVID-19.

Selanjutnya, dari hasil pengelompokan dilakukan analisis deskriptif pada kedua klaster yang dapat dilihat pada Tabel 5 .

Tabel 5. Statistik variabel tiap klaster

\begin{tabular}{lcc}
\hline \multicolumn{1}{c}{ Statistik } & $\begin{array}{c}\text { Klaster } \\
1\end{array}$ & Klaster 2 \\
\hline \multicolumn{1}{c}{ Jumlah desa } & 109 & 68 \\
$\begin{array}{l}\text { Rata-rata jumlah } \\
\text { fasilitas kesehatan }\end{array}$ & 3,17 & 11,57 \\
$\begin{array}{l}\text { Persentase } \\
\text { kejadian COVID- }\end{array}$ & $72,22 \%$ & $97,01 \%$ \\
$\begin{array}{l}19 \\
\text { Rata-rata jumlah } \\
\text { penderita }\end{array}$ & 2,31 & 5,54 \\
COVID-19 & & \\
\hline
\end{tabular}

Dari Tabel 5 dapat dilihat bahwa wilayah desa yang termasuk dalam klaster 1 sejumlah 109 desa memiliki rata-rata jumlah fasilitas kesehatan sebanyak 3,17. Persentase desa dengan kejadian COVID-19 pada klaster ini sebesar 72,22 persen dengan rata-rata jumlah penderita COVID-19 sebanyak 2,31 orang. Sementara itu, sebanyak 68 desa termasuk dalam klaster 2 dan memiliki ratarata jumlah fasilitas kesehatan sebanyak 11,57. Pada klaster ini, persentase desa dengan kejadian COVID-19 sebanyak 97,01 persen dengan ratarata jumlah penderita COVID-19 sebanyak 5,54 orang.

Berdasarkan analisis di atas bahwa rata-rata jumlah fasilitas kesehatan dan penderita COVID19 pada desa klaster 1 lebih sedikit daripada klaster 2. Selain itu, persentase kejadian COVID19 pada klaster 1 juga lebih kecil daripada desadesa klaster 2. Akan tetapi, jika melihat perbandingan jumlah fasilitas kesehatan terhadap persentase kejadian COVID-19 dan jumlah penderita COVID-19, jumlah fasilitas kesehatan mengalami ketimpangan. Jumlah fasilitas kesehatan pada klaster 2 lebih banyak 3,65 kali lipat dibandingkan dengan klaster 1 . Sementara itu, perbandingan kejadian COVID-19 pada klaster 2 adalah 1,34 kali lebih banyak daripada klaster 1 dan perbandingan jumlah penderita COVID-19 pada klaster 2 sebanyak 2,39 kali lipat dibandingkan klaster 1.

\section{KESIMPULAN}

Dari hasil pengelompokan desa menurut potensi fasilitas kesehatan dan kejadian COVID19 di Kota Semarang menjadi dua klaster dapat disimpulkan bahwa jumlah kejadian dan penderita COVID-19 berbanding lurus dengan jumlah fasilitas kesehatan yang ada. Akan tetapi, terdapat ketimpangan jumlah fasilitas kesehatan dibandingkan dengan jumlah kejadian dan penderita COVID-19. Hal ini dapat dijadikan masukan kepada Pemerintah Kota Semarang sebagai target dalam penanganan COVID-19 pada wilayah dengan kejadian dan penderita COVID-19 yang cukup tinggi tetapi memiliki jumlah fasilitas kesehatan yang kurang.

\section{REFERENSI}

[1] H. A. Diah Handayani, Dwi Rendra Hadi, Fathiyah Isbaniah, Erlina Burhan, "Penyakit Virus Corona 2019," Jurnal Respirologi Indonesia, vol. 40, no. 2, pp. 119-129, 2020.

[2] Yuliana, "Corona virus diseases (Covid-19): Sebuah tinjauan literatur," Wellness And Healthy Magazine, vol. 2, no. 1, pp. 187192, 2020, doi: 10.30604/well.95212020.

[3] A. Susilo et al., "Coronavirus Disease 2019: Tinjauan Literatur Terkini," Jurnal Penyakit Dalam Indonesia, vol. 7, no. 1, p. 45, 2020, doi: 10.7454/jpdi.v7i1.415.

[4] Komite Penanganan Covid-19 dan Pemulihan Ekonomi Nasional, "Peta Sebaran COVID-19," 2021. https://covid19.go.id/peta-sebaran-covid19.

[5] S. Pangoempia, E. Grace, and A. Adisti, "Analisis Pengaruh Pandemi Covid-19 Terhadap Pelayanan Kesehatan Di Puskesmas Ranotana Weru Dan Puskesmas Teling Atas Kota Manado," Jurnal KESMAS, vol. 10, no. 1, pp. 40-49, 2021. 
[6] H. Hadiyanto, "Peran Dokter Di Layanan Primer Pada Era Pandemi Covid-19," Jurnal Kedokteran dan Kesehatan: Publikasi Ilmiah Fakultas Kedokteran Universitas Sriwijaya, vol. 7, no. 3, pp. 15-24, 2020, doi: 10.32539/jkk.v7i3.11572.

[7] Badan Pusat Statistik Provinsi Jawa Tengah, Statistik Potensi Desa Provinsi Jawa Tengah 2018. Semarang: Badan Pusat Statistik Provinsi Jawa Tengah, 2018.

[8] G. Gan, C. Ma, and J. Wu, Data Clustering: Theory, Algorithms, and Applications, Second Edition. 2020.

[9] Z. Huang, "Clustering large data sets with mixed numeric and categorical values," Proceedings of the 1st Pacific-Asia
Conference on Knowledge Discovery and Data Mining,(PAKDD), pp. 21-34, 1997, [Online]. Available: http://reference.kfupm.edu.sa/content/c/l/clu stering_large_data_sets_with_mixed_nu_36 2883.pdf.

[10] N. Chen, A. Chen, and L. X. Zhou, "Fuzzy K-prototypes algorithm for clustering mixed numeric and categorical valued data," Ruan Jian Xue Bao/Journal of Software, vol. 12, no. 8. pp. 1107-1119, 2001.

[11] K. Zhou and S. Yang, "Fuzzifier Selection in Fuzzy C-Means from Cluster Size Distribution Perspective," Informatica, vol. 30, no. 3, pp. 613-628, 2019, doi: 10.15388/informatica.2019.221. 